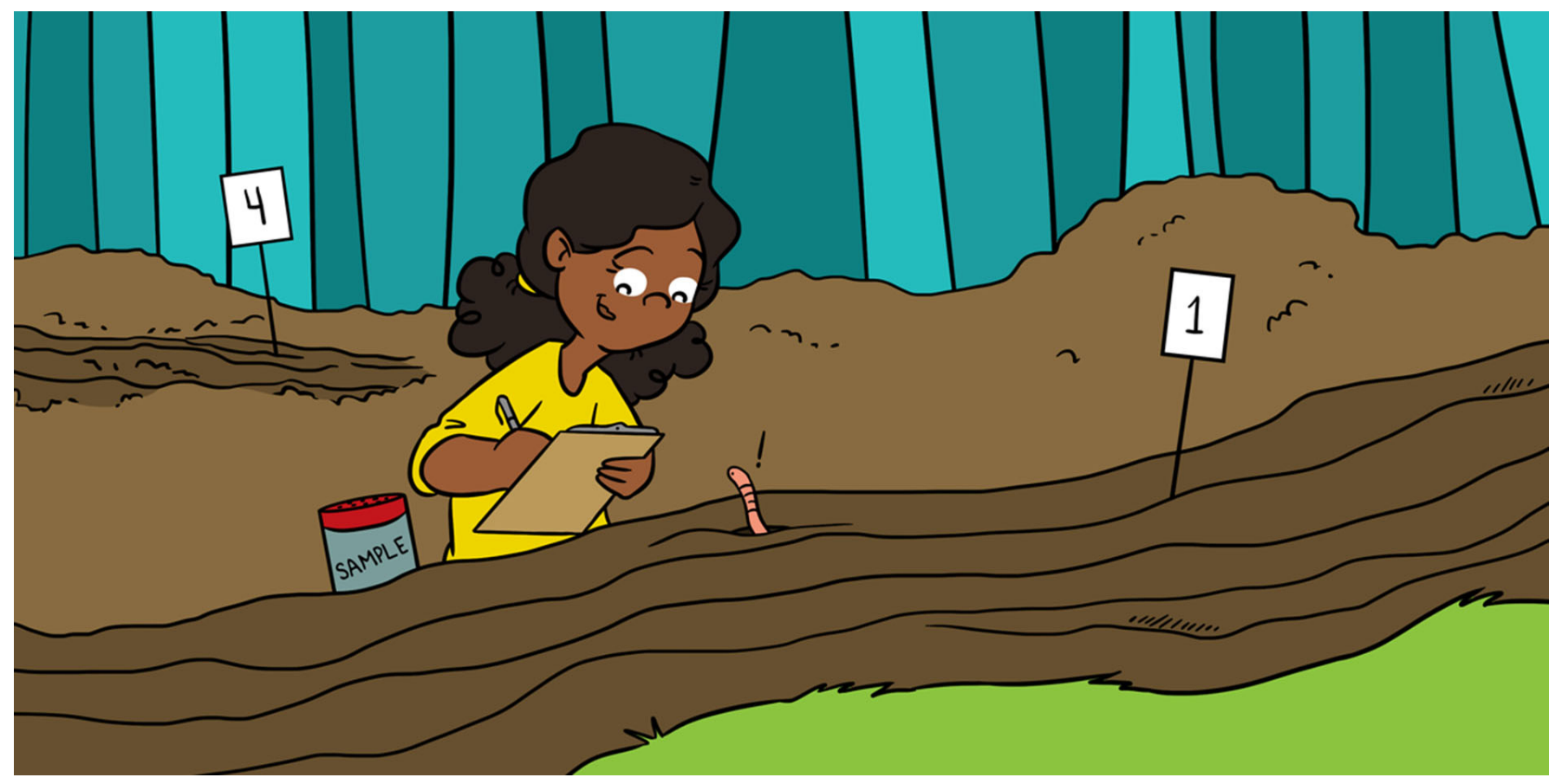

\title{
LOOKING FOR EARTHWORMS IN DEADWOOD
}

\author{
Frank Ashwood ${ }^{1 *}$, Elena I. Vanguelova ${ }^{1}$, Sue Benham ${ }^{1}$ and Kevin R. Butt ${ }^{2}$ \\ ${ }^{1}$ Forest Research, Alice Holt Lodge, Farnham, United Kingdom \\ ${ }^{2}$ Earthworm Research Group, University of Central Lancashire, Preston, United Kingdom
}

YOUNG REVIEWER:

MARIA

AGE: 14
Fallen branches, logs, and tree stumps are a valuable habitat in forests, giving food and shelter to many organisms, including earthworms. Unfortunately, deadwood is often removed from forests because its value is not fully appreciated. We wanted to overcome this by developing a sampling method for earthworms living in deadwood in forests. By testing our new sampling method in oak forests, we found that including deadwood in earthworm surveys improves our knowledge of forest earthworm populations. We also found a greater number of young earthworms in deadwood, where conditions were warmer and moister than in the soil. By surveying deadwood for invertebrates, such as earthworms, we can better understand the important role that deadwood in forests plays in maintaining biodiversity.

\section{EARTHWORMS IN TREES?}

Earthworms are important for maintaining healthy ecosystems: their burrows help air and water enter soil, and they break down dead 
Figure 1

An epigeic

earthworm found in deadwood. The pale band (or "saddle") toward the head end (to the right) tells us this is an adult earthworm.

\section{DEADWOOD}

In forests, woody material that is no longer living, including fallen branches, logs, stumps, and standing dead trees.

\section{EPIGEIC}

Earthworms that live on the surface of the soil in organic matter-rich habitats, like leaf litter.

\section{ENDOGEIC}

Earthworms that make shallow, horizontal burrows, and feed on the soil.

\section{ANECIC}

Earthworms that build deep vertical burrows and feed on organic material on the soil surface.

\section{ORGANIC MATTER}

Matter composed of organic compounds that have come from the remains of organisms, such as plants and animals.

\section{BIODIVERSITY}

The variety of life in a habitat, a high level of which is

usually desirable.

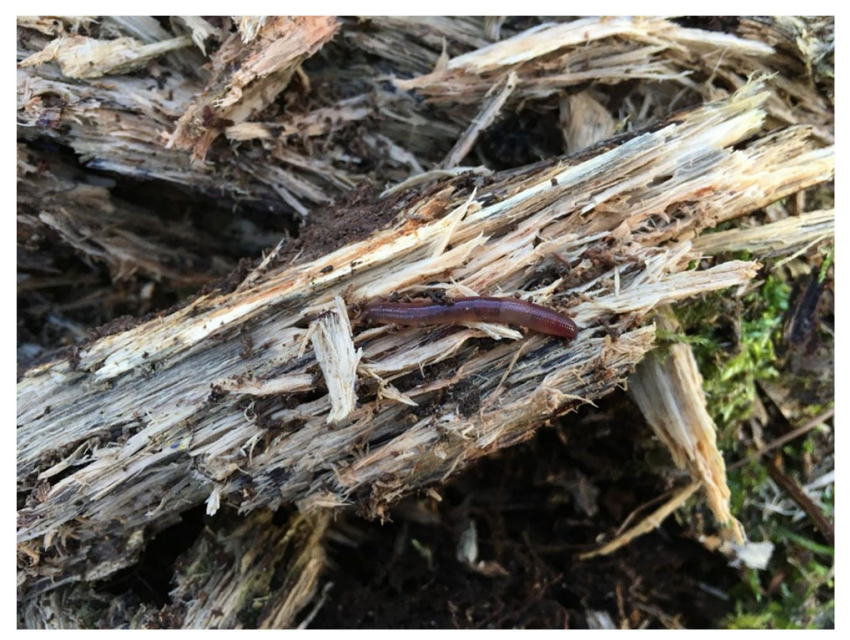

Figure 1

plant material, recycling its nutrients back into the environment. But earthworms do not just live in the ground, they can be found in all sorts of unexpected places-even up in trees and inside logs! Logs and fallen trees are called deadwood and are an important habitat for many different types of earthworm, giving them shelter and food (Figure 1). There are three main groups of earthworms: epigeic (living above-ground), endogeic (shallow-burrowing in soil), and anecic (deep-burrowing in soil) [1]. Earthworm populations in a forest can affect how fast deadwood decays, with different groups and species more important at different stages [2]. This decaying wood is a source of nutrients and organic matter (organic compounds that are the remains of organisms, such as plants), and its decomposition is important for maintaining healthy forest soils.

\section{DEADWOOD IS AN IMPORTANT BUT UNDER-STUDIED HABITAT}

Despite being a key source of soil organic matter and an important habitat, deadwood is often removed from forests when trees are cut down for timber and firewood, putting many species of animals at risk of going extinct [3]. Protecting forest biodiversity is important. Biodiversity is the variety of life in a habitat, and we depend on the services that healthy and highly biodiverse forests provide, such as storing carbon and protecting soil. The more information we can learn about the amount of biodiversity present in deadwood, the better we can understand the importance of keeping it in forests. We do not have a full idea of which earthworms live inside deadwood, because we do not currently have a scientific way of looking for them there. Earthworm surveys normally only look in the soil and may miss earthworms living in other places. By developing a way to survey deadwood for earthworms, we can learn more about earthworm lifecycles and perhaps show how important it is to keep deadwood 
Figure 2

Earthworm sampling in an oak forest plot. Dashed white lines within deadwood indicate sections divided into separate pieces. All deadwood within the plot and $>10 \mathrm{~cm}$ in diameter (dark gray) was measured for total length and midpoint diameter, and five randomly selected pieces of mid- to late decay were sampled for earthworms. All deadwood $<10 \mathrm{~cm}$ in diameter or outside the plot was excluded from the survey (light gray). Five $0.1 \mathrm{~m}^{2}$ soil pits (indicated by crosses) were sampled for soil-dwelling earthworms.

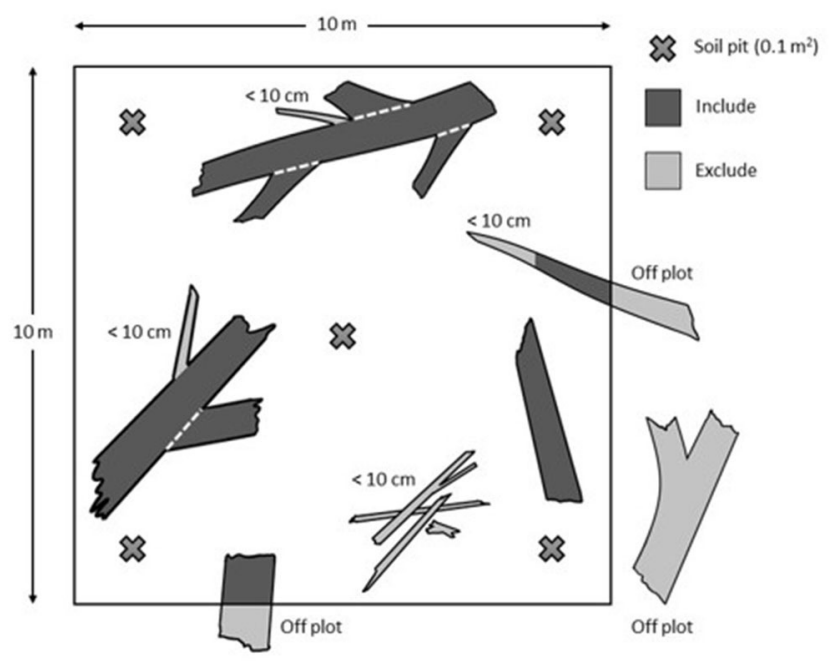

Figure 2

in forests. The main aim of our project was to develop and test a method for surveying deadwood for earthworms. To test whether our method worked, we compared our deadwood results with those from a standard soil-based earthworm survey.

\section{SURVEYING DEADWOOD FOR EARTHWORMS}

To try out our method, we visited 12 forests of common oak trees (Quercus robur) in Surrey, UK, and in each forest, we marked out a $10 \times 10 \mathrm{~m}$ square plot (Figure 2). In each plot, the total volume of deadwood was recorded and we tried to determine which tree species the deadwood belonged to. We also estimated how decayed the deadwood was, based on a 1-to-5 ranking system, in which 1 is least decayed (freshly fallen) and 5 is most decayed (deadwood completely broken down into the soil). Since small branches have very few earthworms in them, we selected five pieces of deadwood that were larger than $10 \mathrm{~cm}$ in diameter, and of mid- to late-decay stage (loose bark and wood beginning to soften). We analyzed the deadwood by placing it onto a sheet and measuring its length and diameter, so we could calculate its volume. Deadwood temperature was measured by inserting a digital kitchen thermometer beneath any loose bark. We then removed any moss and loose bark and inspected it for earthworms, and the remaining wood was taken apart and inspected. Once all earthworms were collected, the deadwood was then returned to its original location, with moss and loose bark replaced as best possible.

\section{SURVEYING SOIL FOR EARTHWORMS}

We also sampled the soil for earthworms using a standard method. This involved digging soil pits $(30 \times 30 \mathrm{~cm}$ wide and $10 \mathrm{~cm}$ deep) 
Figure 3

Summary of the results from the earthworm surveys of soil and deadwood in oak forests.

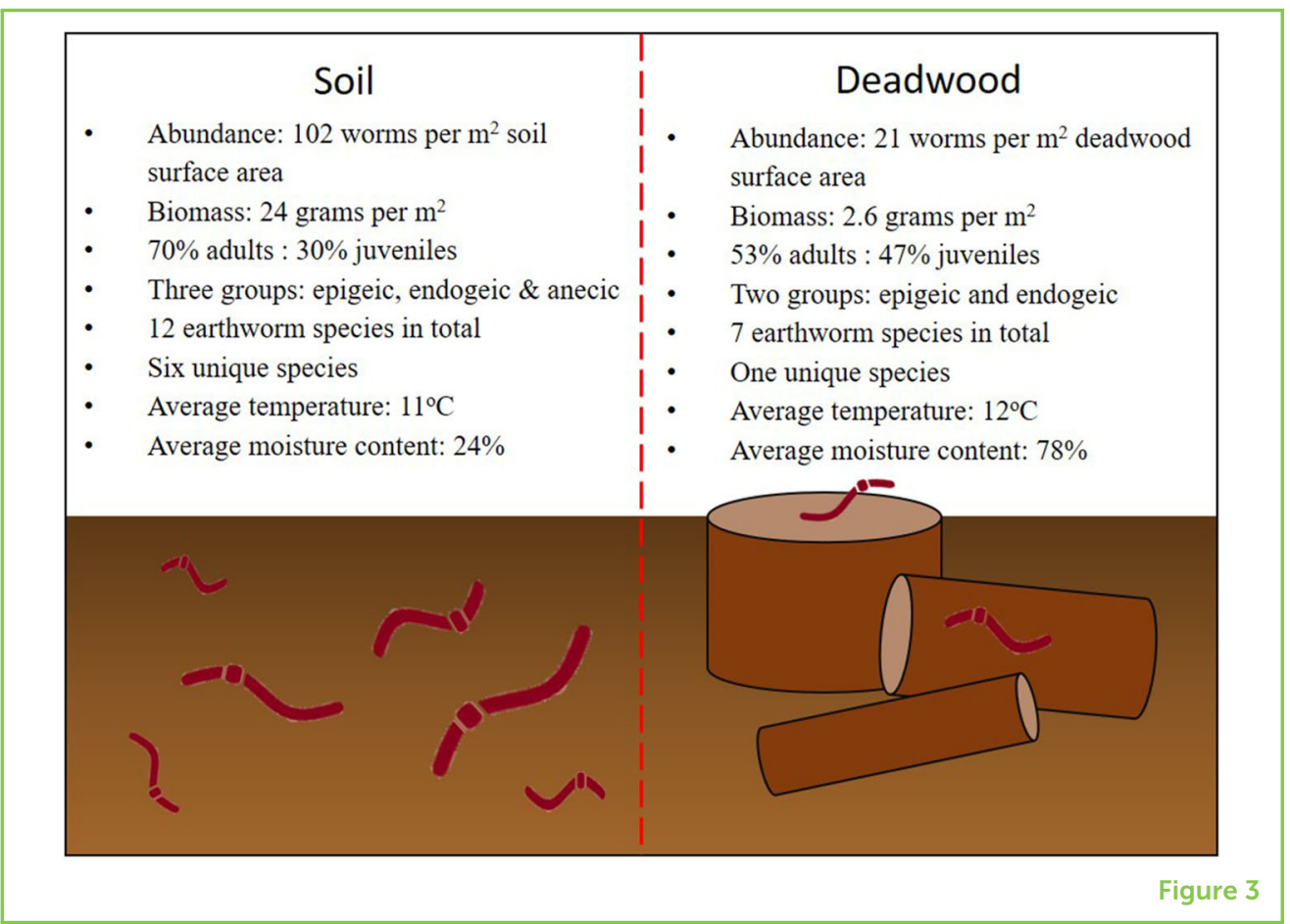

at five locations in the plot (Figure 2). First, we placed the soil onto a sheet to hand-sort for earthworms, and then we poured $5 \mathrm{~L}$ of mustard water $(25 \mathrm{~g}$ of table mustard powder mixed with $5 \mathrm{~L}$ of water) into each soil pit, to extract deep-burrowing earthworms, some of which can dig $2 \mathrm{~m}$ deep! This mustard powder irritates the earthworms' skin and encourages them to come up to the surface. Soil moisture and temperature measurements were also taken. Once all earthworms were collected, the soil was placed back into the holes. All earthworms from deadwood and soil were preserved in alcohol and were weighed, then each species was identified using a microscope and an earthworm identification guide [4].

\section{WHAT DID THE SURVEYS REVEAL?}

Overall, we found a total of 1,012 earthworms and 13 different earthworm species. The number of earthworm species was different between soil and deadwood, with seven species found in deadwood, and twelve species found in soil (Figure 3). One species, Eisenia fetida, was found only within deadwood. This is an epigeic earthworm that is often found in compost heaps. Six species were found only in the soil: two epigeic, three endogeic, and one anecic species. All other earthworm species were found in both deadwood and soil. Many more juvenile (young) earthworms were found in deadwood than soil, and deadwood was much moister than the soil and warmer by around $1^{\circ} \mathrm{C}$. 


\section{ABUNDANCE}

The number of a species or community in an ecosystem, such as the number of individuals per area.

\section{BIOMASS}

The mass of an organism or community of organisms in an area or ecosystem.
Total earthworm abundance (number of individuals) and biomass (mass of all earthworms) was much greater in soil than in deadwood (Figure 3). On average, the deadwood surveys contributed an additional 81 earthworms and $209 \mathrm{~g}$ earthworm biomass per $10 \mathrm{~m}^{2}$ forest plot.

\section{THE BENEFITS OF DEADWOOD SURVEYS}

By adding deadwood to our forest earthworm surveys, we found both a greater abundance of earthworms and more earthworm species than we would have found by doing only soil surveys. There was a much greater proportion of juvenile earthworms inside deadwood, where temperature and moisture conditions were more favorable. Earthworms are very sensitive to temperature and moisture extremes, so being protected in decaying wood allows earthworms to stay active throughout the year, especially during summer drought and freezing winter conditions. Removing deadwood from forests may therefore have a negative effect on the many earthworm species that rely on it for shelter and food. Based on our results, we can say that forest-based earthworm research that does not include deadwood is likely to underestimate earthworm populations, and forests without deadwood will have fewer earthworms. With more development, our survey method could be used for studying other important invertebrates that live in deadwood, such as insects [3]. Hopefully we can use this information to improve forest management practices, to make sure that deadwood is left in place to protect forest biodiversity.

\section{ORIGINAL SOURCE ARTICLE}

Ashwood, F., Vanguelova, E. I., Benham, S. and Butt, K. R. 2019. Developing a systematic sampling method for earthworms in and around deadwood. For. Ecosyst. 6:33. doi: 10.1186/s40663-019-0 193-z

\section{REFERENCES}

1. Hendrix, P. F. 1996. "Earthworms, biodiversity, and coarse woody debris in forest ecosystems of the southeastern U.S.A," in Proceedings of the Workshop on Coarse Woody Debris in Southern Forests: Effects on Biodiversity (Athens, GA). p. $43-8$.

2. Bouché, M. B. 1977. "Strategies lombriciennes," in Organisms as Components of Ecosystems, eds U. Lohm and T. Person (Stockholm: Ecological Bulletin). p. $122-32$.

3. Cálix, M., Alexander, K. N. A., Nieto, A., Dodelin, B., Soldati, F., Telnov, D., et al. 2018. European Red List of Saproxylic Beetles. Brussels: IUCN.

4. Sherlock, E. 2018. Key to the Earthworms of the UK and Ireland. 2nd Edn. Telford: Field Studies Council. 
SUBMITTED: 31 March 2020; ACCEPTED: 20 October 2020;

PUBLISHED ONLINE: 16 November 2020.

EDITED BY: Malte Jochum, German Centre for Integrative Biodiversity Research (iDiv), Germany

CITATION: Ashwood F, Vanguelova El, Benham S and Butt KR (2020) Looking for Earthworms in Deadwood. Front. Young Minds 8:547465. doi: 10.3389/frym.2020. 547465

CONFLICT OF INTEREST: The authors declare that the research was conducted in the absence of any commercial or financial relationships that could be construed as a potential conflict of interest.

COPYRIGHT (c) 2020 Ashwood, Vanguelova, Benham and Butt. This is an open-access article distributed under the terms of the Creative Commons Attribution License (CC BY). The use, distribution or reproduction in other forums is permitted, provided the original author(s) and the copyright owner(s) are credited and that the original publication in this journal is cited, in accordance with accepted academic practice. No use, distribution or reproduction is permitted which does not comply with these terms.

\section{YOUNG REVIEWER}

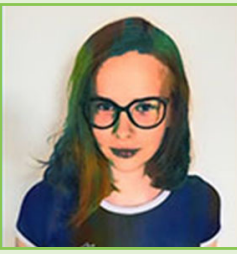

\section{MARIA, AGE: 14}

$\mathrm{Hi}$, my name is Maria and I am from Poland. I absolutely love biology, especially solving tasks in genetics and cell metabolism. In my spare time I enjoy reading books and playing with my cat Roxi. I am keen on ballet. I train regularly at the Dance Conservatory. I really love it!

\section{AUTHORS}

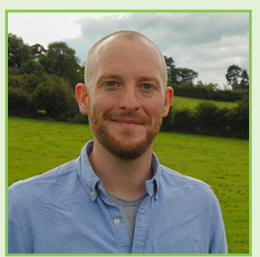

\section{FRANK ASHWOOD}

A passion for nature encouraged me to study Biology at university, where I volunteered for research projects on invertebrate ecology in Scotland and Mexico. After working as an environmental consultant for a few years, I went back to Uni and did a Ph.D. studying earthworms on reclaimed landfill sites. I now have a great job as a soil ecologist for Forest Research, where I study soil biodiversity in UK woodlands. In my spare time I am a soil biology tutor and do macrophotography (taking photos of the tiny animals living in soil). *francis.ashwood(aforestresearch.gov.uk

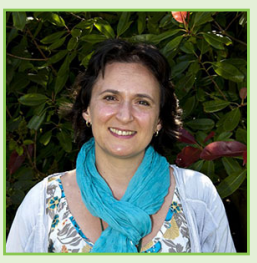

\section{ELENA I. VANGUELOVA}

I have always been an outdoorsy person, spending lots of time in the mountains in Bulgaria as a child. At University I studied Forest Engineering but was not entirely happy until I did my Ph.D. in atmospheric pollution impacts on forest ecosystems. Then I realized that what I really like is the environmental side of forestry and soil. I work at Forest Research as a biogeochemist (a little bit of everything: 


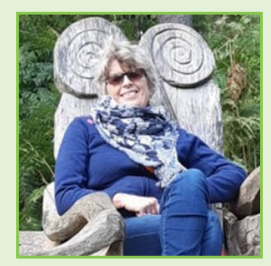

management, and environmental changes on forest soil biogeochemistry.

\section{SUE BENHAM}

I have always loved nature and spent my childhood climbing trees and watching the natural world in the woods around my home. Now I am a scientist at Forest Research and I get paid to do the same thing! I spend my time working to understand how our forests grow and what effect the changing climate is having on their condition. For this I study all aspects of a tree's environment, from the soil around its roots to the air around its leaves and the animals that rely on it.

\section{KEVIN R. BUTT}

Kevin is an ecologist at the University of Central Lancashire. He has studied earthworms for more than 30 years and is interested in how these ecosystem engineers are able to assist humankind through their everyday activities, such as burrowing and eating organic matter. He has studied earthworms throughout Britain and undertaken research across Europe and in the USA. One of his current projects is examining the action of earthworms on Charles Darwin's estate, recreating experiments of the great scientist, whilst another is investigating giant rainworms in the mountains of Germany. 